\title{
ECOPOLITICAL PHILOSOPHY, EDUCATION AND GRASSROOTS DEM OCRACY: THE "RETURN" OF MURRAY BOOKCHIN (AND JOHN DEWEY?)
}

\author{
MICHAEL A. PETERS \\ mpeters@waikato.ac.nz \\ University of Waikato; \\ University of Illinois at Urbana-Champaign
}

\begin{abstract}
This article traces the "return" of Murray Bookchin whose work has been championed by Abdullah Öcalan, one of the founding members and leaders of the Kurdistan Workers' Party (Partiya Karkerên Kurdistanê, PKK). Bookchin's "Democratic Conferalism" serves as a vehicle for taking seriously the notion of the local assembly within a broad non-state framework with an emphasis on inclusiveness and especially women's rights. Öcalan and the PKK have adopted Bookchin's social ecology as the basis for the new society. This article examines Bookchin's "return" in the light of these developments and examines grassroots or participatory democracy as the basis of ecopolitical philosophy and comments on some strong parallels with John Dewey's "creative democracy."
\end{abstract}

Keywords: Bookchin; Kurdistan Workers’ Party; Öcalan; social ecology; participatory democracy; Dewey

How to cite: Peters, Michael A. (2017), "Ecopolitical Philosophy, Education and Grassroots Democracy: The 'Return' of Murray Bookchin (and John Dewey?)," Geopolitics, History, and International Relations 9(2): 7-14.

Received 12 April 2016 • Received in revised form 13 May 2016

Accepted 13 May 2016• Available online 1 June 2016

Murray Bookchin, the American anarchist and pioneering theoretician of social ecology, by his own admission failed to win many converts during his lifetime. Yet before his death in 2006 he influenced and made contact with Abdullah Öcalan, one of the founding members and leaders of the Kurdistan Workers' Party (Partiya Karkerên Kurdistanê, PKK). ${ }^{1}$ The PKK has been 
waging a struggle against the Turkish State since 1984. The revolutionary group founded by Öcalan in 1978 was a blend of revolutionary socialism and Kurdish nationalism aiming at political rights and self-determination for Kurds in Turkey and the establishment of a separate state called Kurdistan. Öcalan was captured by the Turkish National Intelligence Agency with help from the CIA in 1999 and held in sentence of life imprisonment and as sole prisoner on an island for over a decade. ${ }^{2}$ During his lengthy imprisonment Öcalan significantly changed his political position upon reading Murray Bookchin, Immanuel Wallerstein and Fernand Braudel. Drawing on Bookchin's "communalism" he began to theorize what he called "Democratic Confederalism." His works are many; he has written over 40 books including Prison Writings: The Roots of Civilisation (2007), Prison Writings Volume II: The PKK and the Kurdish Question in the 21st Century (2011) and Prison Writings III: The Road Map to Negotiations (2012). In 2004 Öcalan attempted to meet with Bookchin who was too ill. Bookchin issued a statement celebrating Kurdish efforts to establish a rational society and lauded the talents of Öcalan. The PKK reciprocated in 2006 on the death of Bookchin calling him one of the greatest social scientists of the $20^{\text {th }}$ century and vowing to put his ideas into practice. The concept of "Democratic Conferalism" takes seriously the notion of the local assembly within a broad non-state framework putting emphasis on inclusiveness and especially women's rights.

Part of the new ecology and interconnectivity of ideas that is also paradoxically part of a neoliberal project of globalization is how an American thinker (and founder of social ecology) should influence an ethnic group from the Middle East, an Iranian grouping descended from the Hurrians and Medes of some 35 million people (McKiernan, 2006). It is perhaps even more curious that Bookchin's magnum opus The Ecology of Freedom (1982) that maintains that the long-term solution to the ecological crisis is rooted in a new politics of face-to-face assemblies and local democracy should influence the form of political organization adopted by a revolutionary society.

Bookchin's (1962) Our Synthetic Society is one of the very first books even predating Rachel Carson's (1962) Silent Spring that espouses an ecological worldview. ${ }^{3}$ In it Bookchin with considerable foresight remarks:

The problems of our synthetic environment can be summed up by saying that nonhuman interests are superseding many of our responsibilities to human biological welfare....The most pernicious laws of the market place are given precedence over the most compelling laws of biology. http://dwardmac.pitzer.edu/Anarchist_ Archives/bookchin/syntheticenviron/ose1.html

In a later chapter he comments on "The Problem of Chemicals in Food," the title of an article he published as early as 1952 Bookchin depicts as the health 
problem as a shift from home-processed to processed foods under conditions of industrial capitalism that requires greater and great applications of chemicals in agriculture and food processing. As he writes the "attempt to bring the laws of the biosphere into accordance with those of the market place to reduce the natural world to merchandise" has disastrous consequences which are in opposition to environmental health. He advocates among other measures an agricultural and urban regionalism. Bookchin's (1971) PostScarcity Anarchism was part of the anti-capitalist movement of the 1970s and 1980s even though he gave up on anarchism in the late '90s to focus on the notion of "communalism." 4 His biographer Janet Biehl (2013) indicates that as a revolutionary anti-capitalist Bookchin came to the conclusion that the working class were not likely to rise up against the system. The real "limits" to capitalism were ecological and the future rebellion would be the community as a whole in a trans-class interest formation. These ecological ideas he described as coming from Marx himself rather than the anarchist tradition based on "thinking about nonhuman nature and about ecology as a social phenomenon." Biehl cites him as stating: "My basic ideas on an ecological society really came from my decades-long studies of the Athenian polis, Hegel, and even Marx. Specifically, my thinking on ecology was instigated not by the works of any anarchist thinker but by Marx and Engels's remarks on the need to reconcile town and country."

Decentralization was the key guiding idea as an instrument of deconstructing and overturning social hierarchies that gave rise to the domination of nature. Social ecology for Bookchin was:

a fairly integrated and coherent view point that encompasses a philosophy of natural evolution and of humanity's place in that evolutionary process; a reformulation of dialectics along ecological lines; an account of the emergence of hierarchy; a historical examination of the dialectic between legacies and epistemologies of domination and freedom; an evaluation of technology from an historical, ethical, and philosophical standpoint; a wide-ranging critique of Marxism, the Frankfurt School, justice, rationalism, scientism, and instrumentalism; and finally an education of a vision of a utopian, decentralized, confederal, and aesthetically grounded future society based on an objective ethics of complementarity... (Bookchin, "Deep Ecology, Anarcho-syndicalism," pp. 52-53; cited in Biehl at http://theanarchistlibrary.org/library/janet-biehlbookchin-breaks-with-anarchism.html)

Communalism was he answer when he finally broke with the anarchist tradition once and for all substituting a notion of local face-to-face democracy that provided a means of change and a form of praxis that advocated a form of libertarian municipalism, neither individualistic nor nonrational but com- 
mitted to values of social freedom in a way that transcended both Marxism and anarchism.

On Bookchin's notion of social ecology the PPK wrote:

Bookchin broadened the consciousness of humanity: the ecological consciousness. He introduced us to the thought of social ecology, and for that he will be remembered with gratitude by humanity. Through his thesis a great service has also been provided to humanity to achieve a better understanding of itself. Social ecology is not only a product of ecological consciousness, it is also a philosophical and an ideological method which helped to overcome the shortcomings of socialist theory. Therewith important shortcomings of the 19th and 20th century socialism have been completed. ${ }^{5}$

During 2004 Öcalan established a relationship with Bookchin through intermediaries to discuss the significance of eco-democracy and its potential to establish a future body politics for Kurdistan. Beihl indicates that Öcalan wrote in his prison notes that Bookchin's ideas should be read by the municipalities and practiced by them.

Akbar Shahid Ahmed (2015) writing for The Huffington Post under the title "America's Best Allies against ISIS Are Inspired by a Bronx-Born Libertarian Socialist" provides the subheading "Syrian Kurds have launched an unlikely radical experiment in governance without hierarchy, patriarchy or capitalism." He observes that the Syrian Kurds "have built a Bookchininspired society that is the antithesis of the Islamic State." Ahmed reports:

The territory where the 1.5 million or so Syrian Kurds have launched this social experiment, carved out of the wreck of Bashar Assad's police state, includes Kobani and two other small 'cantons,' or regions. They call it all Rojava - 'Western Kurdistan' in Kurdish, the language the Syrian Kurds have only been able to use freely since Assad's control loosened a handful of years ago.

And he goes on the state:

Washington sees the Syrian Kurds' success defending Kobani - and other parts of Rojava - as the chief example of how U.S.-led air power and partnerships with forces on the ground can effectively defeat the Islamic State. ${ }^{7}$

There is so many extraordinary connections and significant ideas here: the power of Bookchin's "social ecology" to inspire the birth of a new society that is fundamentally egalitarian and focused on gender equality; the notion of social ecology that there is a social ecosystem of subjectivities of people that must in some way match or be governed by the physical principles that 
structure our world - a shorthand for participatory democracy as a key value in grassroots decision-making and collective responsibility; the sometimes circuitous route, "translation" and growth that ideas have when they are bedded in a difference culture and context; the notion of the roots of Islamic eco-democracy as an alternative to a strictly male-based patriarchal religious structure; the idea that a group of people can learn from others and are prepared to experiment with forms of democratic that can lead to decisive action.

One hundred years ago John Dewey (1916) wrote Democracy and Education. His pragmatism, championed and revived almost singlehandedly by Richard Rorty (1979), is a form of naturalism that holds knowledge arises from the experience of the human organism in the process of adapting to its environment. This philosophy inspired first by Hegelian idealism increasingly came under the influence of Darwin leading to Dewey's empirical and experimentalist epistemology or as he preferred to call it "theory of inquiry." Dewey's naturalistic logic underlies his work as an educational theorist and his account of democracy as social inquiry that emphasizes the importance of discussion and debate as a mechanism of decision-making. Democracy is a form of "organized intelligence" (Liberalism and Social Action, LW11, 56) not just a means of protecting our interests or expressing our individuality but also a forum for determining our interests. In line with his early interests in psychology Dewey founded the University Laboratory School at Chicago in 1896 that issued in his first major work School and Society (1899) and culminated in his classic work Democracy and Education. An Introduction to the Philosophy of Education (Dewey, 1916), suggesting education for democracy is "sharing in common life." As he asserts in My Pedagogical Creed (Dewey, 1897: 15),

education is a regulation of the process of coming to share in the social consciousness; and that the adjustment of individual activity on the basis of this social consciousness is the only sure method of social reconstruction.

Dewey is the foremost philosopher of education in the twentieth century and perhaps also the most concerned for developing an account of education and democracy - of education as essential democratic institution in building civil society and citizenship.

There are strong parallels between the notions of democracy that Bookchin and Dewey share even if the former proceeds from a trenchant critique of the anti-nature of multinational capitalism while the latter hardly problematizes capitalism or sees the inherent contradictions between them. Yet Dewey helps us construct an alternative political universe by disestablishing the need to seek traditional philosophical foundations for liberalism or to look for these foundations in the metaphysics of the Enlightenment. There is also no 
doubt that in terms of the history of American democracy the first three decades of the twentieth century versus the last three, roughly the socially progressive era with great faith in a universal and comprehensive system of education contrasts strongly with the late post-war era of neoliberalism beginning in 1980 with the election of Ronald Reagan with its emphasis on privatization and charter schools.

The richness and overlapping complexity of Dewey's notion of an organic civil society writ large in education and its multiple institutions leads to a concept of "creative democracy" that might be characterized as "thick democracy" (or even "deliberative democracy"). With the increased massification of education in its primary, secondary and tertiary waves of universalization up to the 1970s - the beginning of the policy era of neoliberalism and first real attempts at privatization - in Deweyean terms one would have thought that education's role in the evolution and development of civil society would have vastly increased. But as we know the opposite is true, neoliberalism and it role in shaping education policy in Western democracy has tended to reduce education's role, to bolster private schools, to put up student fees in $\mathrm{HE}$, to reduce local representation and citizen participation and to substitute market relations for civil relations at every turn. The effect has been to produce democracy in name only - a neoliberalization of democracy that emphasizes an economic analysis and framing. Anthony Downs (1957) was one of the first to apply an economic theory to non-market political decision-making, later adopted by Public Choice Theory.

Neoliberalism proceeds from a critique of social democracy that was developed to transform and tame free market capitalism through a more regulated system that aimed at the establishment of the welfare state and an active labor market policy. Neoliberalism seeks to tame the "big state" by removing regulation and substituting the market for the state in all relations with necessarily a rapid increase in social inequalities and greater control over the market relations of democracy especially through the privatisation of state media and growth of "public relations." Economic liberalism crowds out political liberalism and reduces democracy to market principles: policies as products, voters as passive consumers, politician as producers, elections as markets.

What is worthy of consideration is the ready acceptance by Dewey of the argument of social ecology when it comes to a democracy - of "organized intelligence" (what we might call "collective intelligence" today). There are also good grounds for interpreting Dewey's naturalistic theory of experience as a fundamental ecological perspective and that takes us in the direction of the definition of ecological democracy as sustainability in action - not merely a set of biological processes but simultaneously an orientation of grassroots social and political forces shaping the ecosphere. 
From its development in the 1980s and 1990s Green Political Theory (GPT), founded on the work of Dryzek (1987), Eckersley (1992), Plumwood (1993) and Dobson (1980), participatory democracy has been viewed as a central pillar and key value, often associated with descriptions of "decentralization," "grassroots political decision-making" and "citizen participation," "strong democracy" and conceptions of "deliberative democracy." Despite a number of positive developments including the rapid global spread of democracy in the postwar period, open government and linked data, the recognition of cultural and indigenous rights, and new digital tools promoting collective responsibility and action, the capacity of democracy to address the sustainability crisis seems to have actually declined in the last couple of decades. The decline is in part the result of neoliberal "thin" democracy, economic notions of representative democracy and the action of states supporting the plunder of multinationals. Paradoxically, despite the new awareness of "sustainability" and a myriad number of practical policies of ecological modernization inherent in term sustainable development democratic societies seem to have recoiled from the commitment to fundamental structural change necessary to save the planet. Both Bookchin and Dewey, arch advocates of participatory democracy understand the application of ecology to democracy itself including the principle of its organicity - the grassroots need cultivation, protection and renewal with every new generation.

\section{NOTES}

1. The PKK is listed as a terrorist organization by the EU, USA, Canada, Australia and NZ and has received support from Greece, Syria, Russia, Iran, Armenia and various Eorpean states. It has been engaged in various armed activities since 1974 with a peace process in 1999-2004 and a peace process 2013-2015 before a period of active engagment against the Islamic State with renewed rebellion aginst the Turkish state. See http://thekurdishproject.org/history-and-culture/kurdishnationalism/pkk-kurdistan-workers-party/

2. See "The Öcalan File," http://news.bbc.co.uk/2/hi/europe/280453.stm

3. The book was published under the pseudonym "Lewis Herber." See http:// dwardmac.pitzer.edu/Anarchist_Archives/bookchin/syntheticenviron/osetoc.html

4. See Janet Biehl's "Bookchin Breaks with Anarchism" at http://theanarchist library.org/library/janet-biehl-bookchin-breaks-with-anarchism.html.

5. Cited by Biehl at http://www.biehlonbookchin.com/pkk-salute-bookchin/

6. See http://www.huffingtonpost.com/entry/syrian-kurds-murray-bookchin_us_ $5655 \mathrm{e} 7 \mathrm{e} 2 \mathrm{e} 4 \mathrm{~b} 079 \mathrm{~b} 28189 \mathrm{e} 3 \mathrm{df}$

7. See http://www.huffingtonpost.com/entry/syrian-kurds-murray-bookchin_us_ 5655e7e2e4b079b28189e3df; see also http://www.huffingtonpost.com/entry/us-isissyrian-kurds_us_5655e7a3e4b072e9d1c1641b?jp096bt9 


\section{REFERENCES}

Ahmed, Akbar Shahid (2015), “America's Best Allies against ISIS Are Inspired by a Bronx-Born Libertarian Socialist," The Huffington Post, http://www.huffingtonpost.com/entry/syrian-kurds-murray-bookchin_us_5655e7e2e4b079b28189e3df

Biehl, Janet (2013), Ecology or Catastrophe? The Life of Murray Bookchin. Oxford: Oxford University Press. See also http://www.biehlonbookchin.com/

Bookchin, Murray (1962), Our Synthetic Society. Full text available at https:// libcom.org/files/Bookchin\%20M.\%200ur\%20Synthetic\%20Environment.pdf

Bookchin, Murray (1971), Post-Scarcity Anarchism. Full text available at https:// libcom.org/files/Post-Scarcity\%20Anarchism\%20-\%20Murray\%20Bookchin.pdf

Bookchin, Murray (1982), The Ecology of Freedom. Palo Alto, CA: Cheshire Books. Full text available at https://libcom.org/files/Murray_Bookchin_The_Ecology_of _Freedom_1982.pdf

Carson, Rachel (1962), Silent Spring. Greenwich, CT: Crest Book Reprint. Full text available at http://library.uniteddiversity.coop/More_Books_and_Reports/Silent _Spring-Rachel_Carson-1962.pdf

Dewey, John (1897), My Pedagogical Creed. Full text available at http://playpen. meraka.csir.co.za/ acdc/education/Dr_Anvind_Gupa/Learners_Library_7_Marc h_2007/Resources/books/readings/17.pdf

Dewey, John (1899), School and Society. Full text available at https://archive.org/ stream/theschoolandsoci00deweuoft/theschoolandsoci00deweuoft_djvu.txt

Dewey, John (1916), Democracy and Education. An Introduction to the Philosophy of Education (1966 edn.). New York: Free Press

Dewey, John (1981-1990), Liberalism and Social Action. In The Later Works, 17 vol., JoAnn Boydston (ed.). Carbondale, IL: Southern Illinois University Press. Volume 11.

Dobson, Andrew (1980), Green Political Thought. (4th edn. 2007). London \& New York: Routledge.

Downes, Anthony (1957), The Economic Theory of Democracy. New York: Harper and Row.

Dryzek, John S. (1987), Rational Ecology: Environment and Political Economy. Oxford: Blackwell.

Eckersley, Robyn (1992), Environmentalism and Political Theory: Toward an Ecocentric Approach. New York: State University of New York Press.

Öcalan, Abdullah (2007), Prison Writings. Vol. I: The Roots of Civilisation. London: Pluto Press. See http://ocalan-books.com/english/roots-of-civilisation.html

Öcalan, Abdullah (2011), Prison Writings. Vol. II: The PKK and the Kurdish Question in the 21 st Century. London: Pluto Press.

Öcalan, Abdullah (2012), Prison Writings. Vol. III: The Road Map to Negotiations. London: Pluto Press.

Plumwood, Val (1993), Feminism and the Mastery of Nature. London: Routledge.

Rorty, Richard (1979), Philosophy and the Mirror of Nature. Princeton, NJ: Princeton University Press. 